\title{
Teacher Performance Model Development: Empirical Study on Public Senior High School in Karo District
}

\author{
EddiSurianta \\ Graduate Program, State University of Medan, Indonesia
}

\begin{abstract}
The purposeofthis studyis thefirsttoexaminethe effectoftransformational leadership of principal onself-reflection behavior and performance ofteachers, the effect ofempoweringteachersby the principalonthe behaviorandperformanceof teachers, the influence ofteachersupervisionby the principal on self-reflection behavior and performance of teacher, andinfluencethe self-reflection behavior ofthe teacheronhis/her performance; and, secondly, todetermine themodel ofthe development ofteacher performance. The study designwascorrelationalexplanatoryusing theex postfactoresearch method, andimplementedin the PublicHighSchool ofKaroDistrict. The sampleconsistedof240teacherswas determined using theformulaSlovin, withproportional random sampling technique. Data onexogenousvariablewas collectedby closed questionnaire, anddata onthe endogenousvariable, namelythe performance ofteachers, collectedbyobservation. Data analysisconducted is descriptiveanalysisandpath analysis. The findingsof this studyisthatthere is adirect effectof(1) transformational leadership of principal onself-reflection behavior and performance ofteachers, (2) empoweringteachersby the principalonthe behaviorandperformanceof teachers, (3) teachersupervisionby the principal on self-reflection behavior and performance of teacher, (4) the self-reflection behavior ofthe teacheronhis/her performance, and (5) discoveryof teacher performancedevelopment model, namelyan increase inteacher performancecan be donein twophases, the first phaseby increasingtheability ofprincipalson three areas: transformational leadership, teacher empowermentandteachersupervisionand, second phase, togetherwithimprovingthe ability ofprincipalsinthese areas, and enhancethe ability ofself-reflectionof teachers.
\end{abstract}

Keywords-Transformational leadership, empowerment, supervision, self-reflection behavior, and performance.

\subsection{Background}

\section{INTRODUCTION}

Discussions ofeducationalissues, especially in Indonesia, are always faced withthe eye-chain of problems whichare notclearlytip baseandfromwhere tostart. Teachersmostoftenblamed asthe party mostresponsible forthe quality of education. Gibson [1]describesthreegroups ofvariablesthat affectthe performance ofthe individual, isthe individualvariables, organizationalvariablesandpsychologicalvariables. Individual variablesconsistofabilities and skills, personal background, anddemographics. Organizational variablesconsistofa leadership resource, rewards, structure,and work designvariables. Psychological variablesconsistofperceptions, attitude ofpersonality, andmotivation. Furthermore, Spencerand Spencerin Idawati[2], suggests that the performanceis determinedbythought, andcompetenciespossessed bya person. Based on the opinionsuggested ofGibsonas well asSpencerand Spencer, it can be concludedthat theof teachers' performance is not onlydetermined byof teachersthemselves, but also determined byfactorsexternal to the teachers themselves, especially thefactorof leadershipresources.

With regard tothe ability of teachers, empirical studies showthatthe abilityorcompetenceof teachersinIndonesia is still low. This is evidentfrom theReport ofTeacherCompetency Test(TCT) OnlineFirst Stagein 2012deliveredby the Agency forHuman ResourcesDevelopmentin EducationandCulture and Quality Assurance of Education, Ministryof EducationandCulture[3]that thehighest averagevalue ofTeacher CompetencyTestin Indonesiais51.45achieved bythe provinceof Yogyakarta Special Region, and the lowest was36.70forthe provinceof North Maluku, whiletheprovinceof North Sumatrawithan averagevalue of 40.84 is ranked19thof the33provincesin Indonesia. The reportalsoputKaroDistrictranks11thof30districts/municipalitiesin North Sumatrawithan averagevalue of 41.35. The Ministryof EducationandCulturereportedthat theabilityof teachersin Indonesia, particularlyKaroDistrict, is still low, andalsoto be expected thatthe performanceof teachersinKaroDistrictstill low.

Meanwhile, researchesbyArifin[4]andIndrawati[5]concludedthatteacher certification, which isidenticaltoan increase inincomeandwelfareof teachers; do nothave a significant influenceonthe performanceof teachers. It showsthat theallegationhas beenthat thepoor performance ofthe teacherisdue tolack of teacher's incomeseemsindisputable. In connectiontothe phenomenon ofteacher performancethathas not beenin line with expectations, as noted above, andif associatedtoGibson'stheory proposedthatthe merits ofthe individual's 
performance is determinedbythreefactors, namelyindividual, organizationalandpsychology, then thequestion arises: How isthe performance ofteachersinKaroDistrict? What factorsareaffectingthe performance ofteachersinKaroDistrict?

Therefore, in order to improvethe performanceof teachers of PublicHigh SchoolinKaroDistrict, research onthe development oftheoretical modelsof teacher performance, was conducted. To that end, please be awarewhatmanagementfunctionsarenot optimalin improvingteacher performance. This study was conductedtoassessthe effect oftransformational leadership of principal onself-reflection behavior and performance ofteachers, the effect ofempoweringteachersby the principalonthe behaviorandperformanceof teachers, the influence ofteachersupervisionby the principal on self-reflection behavior and performance of teacher, andinfluencethe self-reflection behavior ofthe teacheronhis/her performance; andtodetermine themodel ofthe development ofteacher performance.

\subsection{Problems Formulation}

The formulations of theproblemin this studyare asfollows:

1. Istransformational leadershiphas adirect effecton the self-reflection behavior ofthe teacher?

2. Isempowermenthasdirect effecton the self-reflection behavior ofthe teacher?

3. Whethersupervisionhasdirect effecton the self-reflection behavior ofthe teacher?

4. Istransformational leadershiphas adirect effecton the performanceof teachers?

5. Isempowermenthasdirect effecton the performanceof teachers?

6. Whethersupervisionhasdirect effecton the performanceof teachers?

7. Is theself-reflection behavior of teacher hasdirect effecton the performanceof teachers?

\subsection{Research Objectives}

In accordancetoformulation of the problem, the purposeofthis studywas to determineandassess:

1. The effectoftransformational leadership of principal onself-reflection behavior ofteachers;

2. The effect ofempoweringteachersby the principalonthe self-reflection behaviorof teachers;

3. The effect ofteachersupervisionby the principal on self-reflection behavior of teacher;

4. The effectoftransformational leadership of principal onperformance ofteachers;

5. The effect ofempoweringteachersby the principalonperformanceof teachers;

6. The effect ofteachersupervisionby the principal on performanceof teacher;

7. Theeffectthe self-reflection behavior on performance of teacher.

1.4 The BenefitsofResearch Results

1. It is expectedthatthe results ofthis studycancontributeto thedevelopment ofthe theory oforganizational behavior, especiallythe performance theory, transformational leadership, empowerment, supervision, andself-reflection behavior.

2. The theoretical modeldevelopedthroughthis researchcouldprovidea theoreticalanswertothe problemsof performance, making it usefulas a modelin improvingteacher performance of PublicHigh SchoolinKaroDistrict.

3. The results ofthis studycouldbe amaterial considerationin the improvement ofteacher performancethrough increasedability of High Schoolprincipalsin terms oftransformational leadership, teacher empowermentandteachersupervision, as well asan increase inself-reflection behavior of teacher.

4. These resultscanbe usedasa reference inthe appointment ofprincipals of High School.

5. The results ofthis studycouldbe afeedback forHigh Schoolteachersin order to understandandimprove their performancethrough increased the self-reflection behavior of teacher.

\section{LITERATURE STUDY}

\subsection{Teacher Performance}

The basic theoryisusedtodiscusstheperformance ofthisdissertationis aperformancetheoryproposed byTRMitchell inRobbins[6]whosaysthatgood performanceis determinedby twofactors:the abilityandmotivation. A considerationin theuseof thistheoryis thatcompliancetothe teaching professionthatrequires the abilityandwillingnessof high. This is in linewith the opinionofPermadiandArifin[7]which statesthat theteaching professionisajob thatrequiresknowledge, skills, expertiseandtenacitytomakechildrenbehaveas expected. Understandingtheteaching professionsuggeststhata teacher's jobisa tough job, so in addition tohavinga high ability, teachersalsomusthave ahigh willingness, thataspiredgoalscan be achieved.

Performanceraised byRobbins, iflinked toteacher performancecanbe measuredbased onthe specificationandcompetencecriteriathatmust bepossessed byeveryteacherin implementinglearning activities, thelearningplan, implementlearningandassessinglearning outcomes. This is in linewith the opinionofRusman[8]which statesthat theformofthe behavior ofteacher performanceis an activityin the learning process, ishowa teacherdevelopslesson plans, implementinglearning activities, andassessing the student learning outcomes. 
Teacher performancecan beviewed asageneralcharacteristicof theteacher, which is associated toknowledge, skillsandthe willingnessof teachersin performing the tasksof teachingthat is realizedthroughacts ofabilityandwillingnessof teachersin preparinglesson plan, ability of teachers in implementingthe learning, and theability of teachers toimplementassessmentof learning. The formofteacher performanceis measuredthroughthe lookandthe activities carried outbythe teacherin thelearningactivitiesishow teacherspreparelesson plans, implement the learningandassess thelearning outcomes, while theappreciation of thetask, thoughitexists,is consideredto havea less significanteffectin the context ofmotivationworkofteachersatthis time. This is in linewith theopinion ofthe WinaSanjaya[9], whostatedthat theteacher's performance on the tasksof planning, learningmanagementand assessment ofstudent learning outcomes.

Performance ofsomeoneis alwaysassociatedwith theroutine taskshe is performing. Likewise withthe performance of teacherswhohave the certain specifications/criteriain carrying outits core functions,namelyto implementthe learningprocess. Teacher performancecanbe seenandmeasuredbased on competency specifications/criteriathatmust bepossessed byeveryteacher. The realizationofthe performance ofthe teacherin thelearningactivitiesishow teacherspreparelesson plans, implement the learningandassess thelearning outcomes.

The planning stageis the stagein the learning activitiesrelated to theability of teacherstomaster theteaching materialsthatis expressed inthe abilitytopreparelesson plans. Mulyasa[10]saysthat theplanis acentral functionofmanagementof learningandshould beorientedto thefuture. Stages ofimplement the learningactivitiesin theclassroomis the essenceofeducation. Learningis essentiallyatransactionalcommunication process, whichis reciprocal, bothbetweenteachersand students andbetween students andstudents, andbetweenstudentsand thelearning resourcestoachieve thegoals set. While thelearningassessment phaseis the phaseof activityor thewaythatis intendedtodeterminewhether or not thelearning objectivesachievedand thelearningprocesshas beenconducted.

\subsection{Transformational Leadership of Principal}

Hall,Johnson, Wysocki, andKarlKepner[11], HesselbeinandCohen[12]agreedthat a leaderwhoappliestransformational leadershipcanbe an effective leader. It showsalso thatif the principalcanimplementtransformational leadershipwellit stands to reasonthatthe principalwill beable tochange the behaviorof teacherstowardsthepositiveand, subsequently, the performanceof teacherswill increase. This is in linewith the opinionofNorthouse[13]whosaysthateffectivetransformational leadershipwillresult inperformancethatexceeds theexpectations ofthe organization, becausethe leadershould work withall componentstoachievethese goals.

Indeed, theleadershipdimensionsvaryaccordingto the experts, as presented byGibsonetal. [14]which statesthat thedimensionsof leadershipinclude: (1) Charisma, (2) Attentionto the individual, (3) Encouragebyknowledge, (4) Give a gift; (5) Management ofexception. Lunenburgetal. [15]saysthat theleadershipdimensionsare(1) Contrast, (2) Motivatethesubordinatestodomore thantheyoriginally; (3) Raisingfollowersneedleveltothehigher-order needsuchasself-actualization, orbyexpandingtheirportfolioofneeds. Meanwhile, according toBassandAvolio[16](2005: 367) transformational leadershipdimensionsare(1) Charisma; (2) Encouragingthroughinspiration, (3) Encouragebyincreaseof knowledge, (4) Consideration ofthe individual.

Based on thedimensions oftransformational leadershippresented above, thetheoretical basis thatis usedas a toolof analysisinthisdissertationisreferringto thetheory oftransformational leadershipthatwas createdbyBernardBass. The basicconsiderationsin theuse ofthetheoryisdue to thematchon the field, where theschoolasaninstitution of humanresourcedevelopmentrequiresthatthe principalhasstrong leadershiptoproducea wide range ofpolicyandoperational workis based onthe visionthat formed the basisof theachievement ofschool goals, andleadershipofprincipalsare alsoexpected toinspireteachers and education staffto excelinschool.

\subsection{Teacher Empowerment}

In educational reforminIndonesia, the empowermentof teachershavebelievedas an important componentin improvingquality of education, so was bornthe law of the Republic of Indonesia number 14 of 2005teachersandlecturers. Whenreviewingthe opinion of expertsonempowermentsuch asLuthans[17]andSchermerhornetal. [18], theybasicallysaidthatempowermentgivespowerto peoplewhoneed it, so thattheemployeemore efficientandmoreprofessionalin carrying outtheir duties.

Managing the teacher is notan easyjob, because according to theadherents ofthe theoryview ofhuman resources, namelyDouglasMcGregorinNelsonandQuick[19]states thattounderstandhumanorhuman behaviorthere isan assumptionthatmustbe understood, thetheoryY.AssumptionsofTheory Ystatesthathumanslove to work. Based onthe theory ofY, ifin aschoolorganizationthere areteacherswho embracethe theory ofY, thenthere needs to beempowering. Principals shouldcreate a climatethatprovides opportunitiesforpersonaldevelopmentteacher.

Based on thetheoryofempowerment of Luthans[20], ClutterbuckandKernaghan[21], andMcShaneandGlinow[22], theempowermenttheoryused inthis studyas the basis ofthe theoryis a theoryof empowermentcreated byClutterbuckandKernaghan. Considerationsin theuseof thistheoryare, first, ClutterbuckandKernaghanusingdimensionsof education anddevelopmentin an effort toempowermembers ofthe 
organization. Whileother expertsdid not includedevelopmentas onedimensionof empowerment, interms of the developmentis an integral partof the life ofan employee(a person) to achievecareeradvancement. Secondly, there is a matchwith thephenomenaencountered in the field, althoughemployeeshave beenempoweredbut have not demonstratedan optimal performance. Therefore, ClutterbuckandKernaghanarguesthatthere are5(five) dimensionsthatdetermine the success ofan organizationthathasempowered, namely: (a) the objectives, (b) managementattitudes, (c) traininganddevelopment,(d) selection and recruitment ofemployees, (e) structureandsystems.

\subsection{Teacher Supervision}

Managing the teacher is not an easy job, because according to theadherents ofthe theoryview ofhuman resources, namelyDouglasMcGregorinNelsonandQuick[23]states thattounderstandhumanorhuman behaviorthere isan assumptionthatmustbe understood, thetheory X. Based onthe theory of X, if in a school, it was found that teachers are lazy to work, then the required supervision. Supervision is intended in this study, was supervision conducted by principal to teachers in the form of academic supervision and administrative supervision. Academic supervision is supervision that focuses observations on the problem of learning activities that teachers do to help students when it is in the process of learning, and administrative supervision is supervision that focuses observation on the administrative aspects that support the implementation of learning.

Based on the supervision of theories put forward by the experts, namely Robbins and Coulter [24], Winardi[25], and Handoko[26], then the basic theory of supervision used in this study is the theory of supervision described by Robbins and Coulter[27]that surveillance is a systematic attempt by the principal to the teacher's performance which includes academic supervision and administrative supervision, to ensure that the execution of work in accordance with the objectives of the organization, with dimensions of (1) establish standards, (2) measuring / carry out an assessment to classroom , (3) compare the plan with results that have been achieved, and (4) implementing corrective action and improvement. A consideration in the use of this theory is due to the dimensions of a standard-setting in this theory. This is also in line with the implementation of the school, where the government sets 8 national standards that must be implemented in each year of education. This standard were used to measure the achievement of the implementation of education, and subsequently this standard is also used in carrying out supervision functions are carried out either by the principal or school superintendent.

\subsection{Self-Reflection Behavior of Teacher}

Kemmis[28]describes the behavior of self-reflection is a process that involves the examination of conscience and thought process, and beyond consideration of the situation in which the individual finds himself. Thus, reflection is a mirror to practice for open-mindedness and responsibility. Kobuchi in Asep[29]describe the awareness of teachers in Japan about the importance of self-reflection behavior that resulted in a change to a better direction in learning, because of previous errors can be fixed in the next lesson. Furthermore, Wiggens[30]in his book Student Teacher in Action wrote about the self-portrait as an educator, he wrote that a teacher should be able to look in the mirror at him-self. While Boud, Keogh and Walker in DianthaSoemantri[31]says that the process of self-reflection is starting from asking and dialogue with oneself through three questions, namely: (1) what happened?, (2) how did happen?, and (3) what has been learned?, what changed or what has to be done?. This opinion explains that in order to make changes to the teaching behavior for the better in efforts to improve its performance, a teacher needs to have a dialogue with himself and asked what he had done in the classroom, how he did it, and what changes in his students, and what changes should be done to improve the implementation of learning.

Korthangen et al. [32] argues ALACT models, which describe structured reflection process, and if the teacher implementing this model in the implementation of any learning, then the teacher will be able to independently increase teacher professionalism so that the performance will increase. While learning model reflection of Zeichner and Liston stressed the importance of teacher self-reflection, to ask your-self back to what teachers teach, and subsequently in the presence of self-reflection will be able to improve the performance of teachers. Therefore, the model of Boud, Keogh \& Walker, as well as the model proposed KarthangenZeichner\& Liston have a common view of the behavior of self-reflection, is the activity of thinking and ask your-self what has been, is and will be implemented in order to improve the quality of learning.

Of the various models of the behavior of self-reflection mentioned above, it is used as a theoretical basis in this study is a modification of the model presented Boud, Keogh \& Walker, Karthangen, and Zeichner\& Liston, and the behavior theory described by Robbins with the dimensions of self-reflection behavior include: (1) attitude, (2) personality, (3) perception, (4) learning, and (5) are always thinking and dialogue to himself, about his work (ask yourself). A consideration in using a modification of this theory is as follows. First, the theory of behavior Robbins created containing the attitude and personality, where attitudes are showing the consistency of the behavior of individuals that must be owned by a teacher, because the teacher is not merely a 
profession, but also a humanitarian duty calls. Therefore, the philosophy in understanding human behavior framework should include elements of attitude as pillars, or without understanding the attitudes element for understanding individual behavior is wrong (not quite right). Second, the most important part of the behavior of self-reflection is always thinking and dialogue about the work yourself or, in other words, have an attitude that is always asked about what has been, is being and will be done.

Based on theoretical studies, and the thinking framework outlined above, a theoretical model of the study variables was formed as in Figure 1 below.

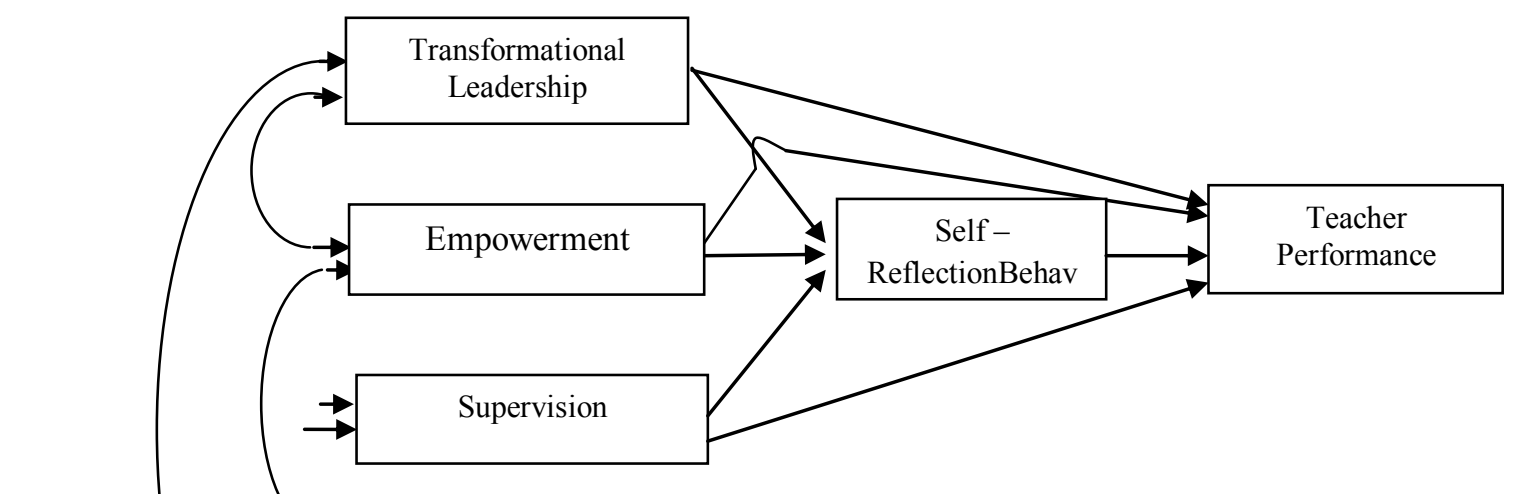

Figure 1:Research Paradigm

\subsection{Sample}

\section{METHODOLOGY}

The study sample consisted of 240 respondents, which is obtained by using the formula of Slovin, then the number of Samples specified in each High School which is spread over thirteen (13) the location of the school according tathe latest education and gender based on the proportional random sampling.

\subsection{Data Analysis}

The design of this study is correlational explanatory with ex post facto research method. Data collection techniques used are non-test technique that consists of a closed questionnaire that followed the pattern of the 5choice Likert scale adapted to the content of the statement set out to collect data on the variables of transformational leadership (34 items), empowerment (34 items), supervision (35 items), and self-reflection behavior (35 items). Data on transformational leadership, empowerment and supervision are describe teachers' perceptions of what is seen, felt and experienced by teachers on transformational leadership, empowerment and supervision conducted by the principal. Data on the self-reflection behavior of the teacher is obtained through a closed questionnaire filled out by the teacher about the behavior that they do in performing everyday tasks. Furthermore, to obtain data on the performance of teachers, observation sheets were used (50 items). This technique is used to obtain primary data, is data obtained directly from research subjects.

There are two techniques of data analysis used in this study, namely the descriptive analysis and inferential analysis. Descriptive analysis is used to interpret the data picture of the variables that represent the answer to the research question. Inferential analysis is used to analyze the sample data to generalize the population, and hypothesis testing is done by using path analysis. As research tool for data analysis SPSS for Windows version 21 software is used for this research.

\section{RESULTS OF THE STUDY}

Table 1: Summary of Results of theDescriptiveAnalysisData Research Variable

\begin{tabular}{lccccccc}
\hline \multicolumn{1}{c}{ Factors } & $\begin{array}{c}\text { Respondent } \\
(\mathrm{N})\end{array}$ & Mean & $\begin{array}{c}\text { Std } \\
\text { Deviation }\end{array}$ & Minimum & Maximum & $\begin{array}{c}\text { Minimum } \\
\text { Ideal }\end{array}$ & $\begin{array}{c}\text { Maximum } \\
\text { Ideal }\end{array}$ \\
\hline $\begin{array}{l}\text { Transformational } \\
\text { Leadership }\end{array}$ & 240 & 3.04 & 0.28 & 2.47 & 3.76 & 1 & 5 \\
Empowerment & 240 & 3.02 & 0.30 & 2.41 & 3.79 & 1 & 5 \\
Supervision & 240 & 2.89 & 0.28 & 2.29 & 3.71 & 1 & 5 \\
Self-Reflection & 240 & 2.74 & 0.25 & 2.20 & 3.40 & 1 & 5 \\
Behavior & & & & & & & \\
\hline
\end{tabular}




\begin{tabular}{llllllll}
\hline $\begin{array}{l}\text { Teacher } \\
\text { Performance }\end{array}$ & 240 & 2.38 & 0.17 & 1.96 & 2.90 & 1 & 4 \\
\hline
\end{tabular}

Based on Table 1 was obtained that there are two variables have a mean enough, is the principal transformational leadership, and empowerment of teachers by principals, while the other three variables are included in the unfavorable category, namely the supervision of teachers by principals, self-reflection behavior of the teacher, and teacher performance. Variable with the highest mean is transformational leadership, while the lowest is the variable of teacher performance.

Table 2: Summary of Results of the Correlation Coefficient and Significance

\begin{tabular}{lcccr}
\hline & Endogenous Variable & \multicolumn{2}{c}{$\begin{array}{c}\text { Self - Reflection } \\
\text { Behavior }\end{array}$} & \multicolumn{2}{c}{$\begin{array}{c}\text { Teacher } \\
\text { Performance } \\
\text { Exogenous Variable }\end{array}$} & $\begin{array}{c}\text { Pearson } \\
\text { Correlation }\end{array}$ & Significance & $\begin{array}{c}\text { Pearson } \\
\text { Correlation }\end{array}$ & Significance \\
\hline $\begin{array}{l}\text { Transformational } \\
\text { Leadership }\end{array}$ & $.743^{* *}$ & .000 & $.806^{* *}$ & .000 \\
Empowerment & $.609^{* *}$ & .000 & $.692^{* *}$ & .000 \\
Supervision & $.632^{* *}$ & .000 & $.763^{* *}$ & .000 \\
Self-Reflection Behavior & & & $.853^{* *}$ & .000 \\
\hline
\end{tabular}

**Correlation is significant at the 0.01 level (2-tailed)

Table 2 shows that the exogenous variables have a positive relationship (strong) and significant with the endogenous variable (the self-reflection behavior of the teacher). The most powerful relationships in the model 1 is shown by transformational leadership variable (0.743). As for model 2 is obtained that the exogenous variables have a positive relationship (strong) and significant with the endogenous variable (teacher performance). Having the strongest relationship with the teacher's performance is variable self-reflection behavior of teacher (0.853).

Table 3: Total Effect, Indirect Effect, and Direct Effect

\begin{tabular}{l|c|c|c|c|c|c}
\hline \multirow{2}{*}{$\begin{array}{l}\text { Exdogenous Variable } \\
\text { Exogenous Variable }\end{array}$} & Self - Reflection Behavior & \multicolumn{2}{c}{ Teacher Performance } \\
\cline { 2 - 7 } & TE & IE & DE & TE & IE & DE \\
\hline $\begin{array}{l}\text { Transformational } \\
\text { Leadership }\end{array}$ & 0.507 & - & 0.507 & 0.427 & 0.239 & 0.188 \\
\hline Empowerment & & & & & & \\
\hline Supervision & 0.141 & - & 0.141 & 0.186 & 0.067 & 0.119 \\
\hline Self - Reflection Behavior & 0.199 & - & 0.199 & 0.360 & 0.094 & 0.266 \\
\hline $\mathrm{R}^{2}$ & - & - & - & 0.472 & - & 0.472 \\
\hline \multicolumn{2}{|c|}{ Note. TE = Total effect, IE = Indirect effect, DE = Direct effect; All direct effects were significant at .01 level. }
\end{tabular}

Table 3 shows that all exogenous variables (the principal transformational leadership, empowerment of teachers by principals, and supervision of teachers by the principal) have a partial positive direct influence on the endogenous variable (the self-reflection behavior of the teacher). Similarly, exogenous variables (the principal transformational leadership, empowerment of teachers by principals, supervision of teachers by the principal, and self-reflection behavior of teacher) have a partial positive direct influence on the endogenous variable (the self-reflection behavior of the teacher). The most influential variable on teacher self-reflection behavior is transformational leadership 0.507 , while the most influential variables on the performance of the teacher are a teacher self-reflection behavior of 0.472 . Based on the total effect, is direct and indirect influence, it turns out the relationship between exogenous variables to endogenous variables found to support all of the hypotheses in the research model.

Based on the coefficient determinant of Model I, the combined effect of transformational leadership of principal, empowerment of teachers by principals, and teacher supervision by principals on teacher self- 
reflection behavior was found to be $58.9 \%$, while the remaining $41.1 \%$ is influenced by other factors. Furthermore, based on the determinant of the coefficients of Model II, the combined effect of transformational leadership, empowerment, supervision, and self-reflection behavior on teacher performance was found to be $84.0 \%$, while the remaining $16.0 \%$ is influenced by other factors. So based on the results of the study found that the path diagram that describes the structure of a causal relationship between exogenous variables with endogenous variables are as depicted in Figure 2 below.

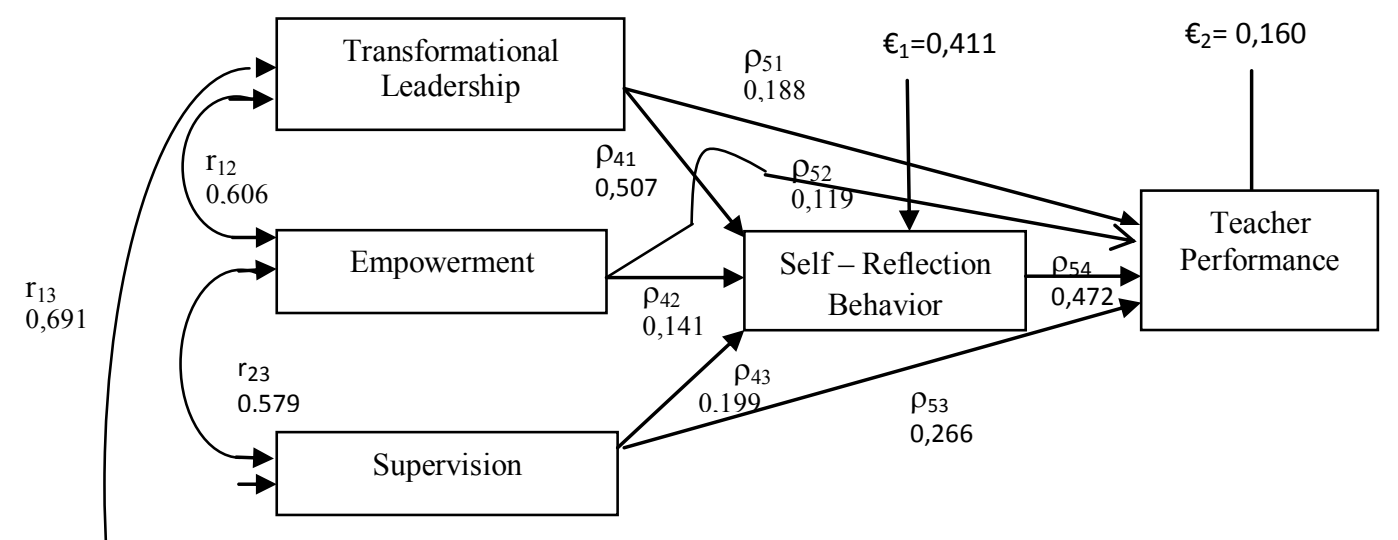

Figure 2:Path Diagram of Research Variables

\section{DISCUSSION}

Based on the first hypothesis test of the study's findings, a significant path coefficient between transformational leadership principals with self-reflection behavior of teacher self-reflection is 0.507 . This finding is consistent with studies by Roger J. Givens who found that transformational leadership has a direct influence on the behavior of individuals within the organization, and also has a direct influence on performance, organizational cultuxe, and vision of the organization. The findings of this study support the theory of the behavior and performance of Gibson, who explained that there are three groups of variables that affect work behavior and performance, namely: the individual variables, organizational variables and psychological variables. One of the variables that affect behavior and performance of individuals is leadership. Thus, the results of this study indicating that school leadership has a direct positive influence on teacher self-reflection behavior is consistent with the results of research and theoretical basis used.

Based on the second hypothesis test of the study's findings, a significant path coefficient between empowerment of teachers by principals with self-reflection behavior of teacher is 0.141 . The findings of this study support the theory of Clutterbuck and Kernaghan who said that empowerment is characterized by the presence of (a) purpose, (b) the attitude of management, (c) training and development, (d) selection and recruitment of employees, and (e) structures and systems, which will increase a person's behavior and performance. Furthermore, the findings of this study also supports the theory $\mathrm{Y}$ of Douglas McGregor which assumes that man is happy to work, so if there is a school teacher who embraced the theory $\mathrm{Y}$, then the empowerment needs to be done by the principal. The more powerful or more powerful teacher, the more adds to its ability to make improvements in their work through self-reflection. Thus, the results of this study indicating that the empowerment of teachers by principals has a direct positive effect on teacher self-reflection behavior are consistent with the results of research and theoretical basis used.

Based on the third hypothesis test of the study's findings, a significant path coefficient between supervision of teachers by principals with self-reflection behavior of teacher is 0.141 . The study's findings are in line with study by Galvin stated that the leaders will spend $50 \%$ of their time handling quality control. This means that in order to change the behavior of the teacher from waiting for orders to active implement improvements to learning through self-reflection behavior, then increased supervision needs to be done by the principal. The findings of this study also supports the theory X of Douglas McGregor stated that the man was not going to work even always avoid it. From the research findings it appears that there is a significant effect of supervision on the behavior of self-reflection, therefore, it can be said that there are still teachers who embraced the theory of $\mathrm{X}$, so that the role of supervision by the principal needs to be improved. Thus, the results of this study indicating that the supervision of teachers by principals has an influence on the self-reflection behavior of the teacher is in accordance with the results of research and theoretical basis used.

Based on the fourth hypothesis test of the study's findings, a significant path coefficient between transformational leadership of principal with performance of teacher is 0.188 . The findings of this study are consistent with the studies of Roger J. Givens who found that transformational leadership has a direct influence on the behavior of individuals within the organization, and also has a direct influence on performance, 
organizational culture and vision of the organization. These findings also support the Model of Organizational Behavior Systems of Newstrom who explaining that the leadership has a direct effect on performance, and supports the Components of Individual Performance of Mathis and Jackson explaining that one of the factors that affect the performance of the individual is the support of organization, which among others, is leadership, and supports the theory of Behavior and Performance of Gibson who explaining that there are three groups of variables that affect work behavior, and performance, namely: the individual variables, organizational variables, and psychological variables. Thus, this study found that the principal transformational leadership has a direct positive effect on teacher performance is in accordance with the results of research and theoretical basis used.

Based on the fifth hypothesis test of the study's findings, a significant path coefficient between empowerment of teachers by principal with performance of teacher is 0.119 . The findings of this study are consistent with the research of DjonniBangun which found that there was a significant effect of simultaneous empowerment and motivation of teachers on the performance of professional teachers. This findingis also in linewithstudiesbyGasperszstatingthatemployee'sfeelempoweredwhenthey are: (1) their workistheir own, (2) they areresponsible, (3) theyknowwhere they are, and(4) theyhavesomecontrolover their work, whichtherebywill improvetheir performance. Furthermore, the research findingsalsosupport the theoryY ofDouglasMcGregorwhichassumesthat man ishappytowork, soifthere isa teacherat theschoolwho holdthistheoryY, theempowerment ofteachersneeds tobe doneby the principal. Thus, the results ofthis study indicatethat theempowermentof teachersbyprincipalshavea directpositiveeffecton the performance ofteachersin accordancewith the resultsof researchandtheoretical basisused.

Based on the sixth hypothesis test of the study's findings, a significant path coefficient between supervision of teachers by principal with performance of teacher is 0.119 . The study's findingsare consistentwith the resultsofEliezerYarivresearchthat showsthatthere are threemain sourcesthat causepoorteacher performance, namely: (1) poormanagementandsupervision, this is indicatedto20percent ofrespondents statedthat thepoor performance ofteachers, isduetomanagementthatthe principal does notrunright, andpoorsupervisionby the principal, (2) weaknessof teachers, thelackof knowledgeandexperience, disparities in ability toperformthe work in accordancewiththe demands of work, decreased motivation, and personality disorders(stress andfatigue), and (3) external influencesor non-work related to the teacher, which isassociatedwith ateacher's personal life factors(financial, divorce, etc..). The findingsof this studysupport thetheoryXofDouglasMcGregorrespect tothosewhoembraced the theoryof $\mathrm{X}$, whichin this casewouldbe requiredto increase supervision. Based onthe researchfindings, it is known thatthere isa significant effectofsupervision on theself-reflection behavior, thusit can be saidthatthere are stillteacherswhoembraced the theoryof $\mathrm{X}$, so thatthe role ofsupervisionby the principalwould need tobe improved. Thus, theresults ofthis studyindicatingthat thesupervisionof teachersbyprincipalshas an influenceon the self-reflection behavior ofteacherisin accordancewith the resultsof researchandtheoretical basisused.

Based on the seventh hypothesis test of the study's findings, a significant path coefficient between the self-reflection behavior ofteacher with performance of teacher is found, which is 0.472 . The findingsof this studyare consistent with theresearchofNavaneedhanwhichindicatesthat theself-reflectionbehavior of teacher in teachinghas to dowiththe continuous professionalgrowthofteachers, teacherself-reflection behaviorin developingcritical thinkingandenhance thelearning experienceof teachers, andself-reflection behavior of teacher in enhancingpersonal growthteacher. This findingis in linewithempiricalexperiencein developingKobuchiLesson StudyinJapan, where there is ahighawareness ofthe behavior ofteacherself-reflectionwillencourageteacher performanceto abetter direction, especiallyin learning, becauseof previous errorscan be fixedinthe nextlesson. The findingsof this studyalsosupport the studybyClarke\&Croftwhoshowedthat thepractice ofselfreflectionbehaviorcandevelopandimprove theprofessionalismof teachers. Thus, theresults ofthis studyindicatingthatteacherself-reflection behaviorhasa direct influenceon the performanceof teachersisconsistent with the resultsof researchandtheoretical basisused.

Thus, according tothe results ofresearchthroughthe seventhtest ofthehypothesisof the proposed research, was foundaTheoreticalModelofTeacher PerformanceofHigh Schoolthat describesthe structure ofa causalrelationshipbetweenthe variablesofthe principaltransformational leadership, empowerment ofteachersby principals, supervisionteacherby the principal, teacherself-reflection behavior, andHigh Schoolteacher performance. Furthermore, based onthe researchfindings, it can be proposeda"Model of theDevelopment ofTeacher Performance of High School" as showninFigure3. 


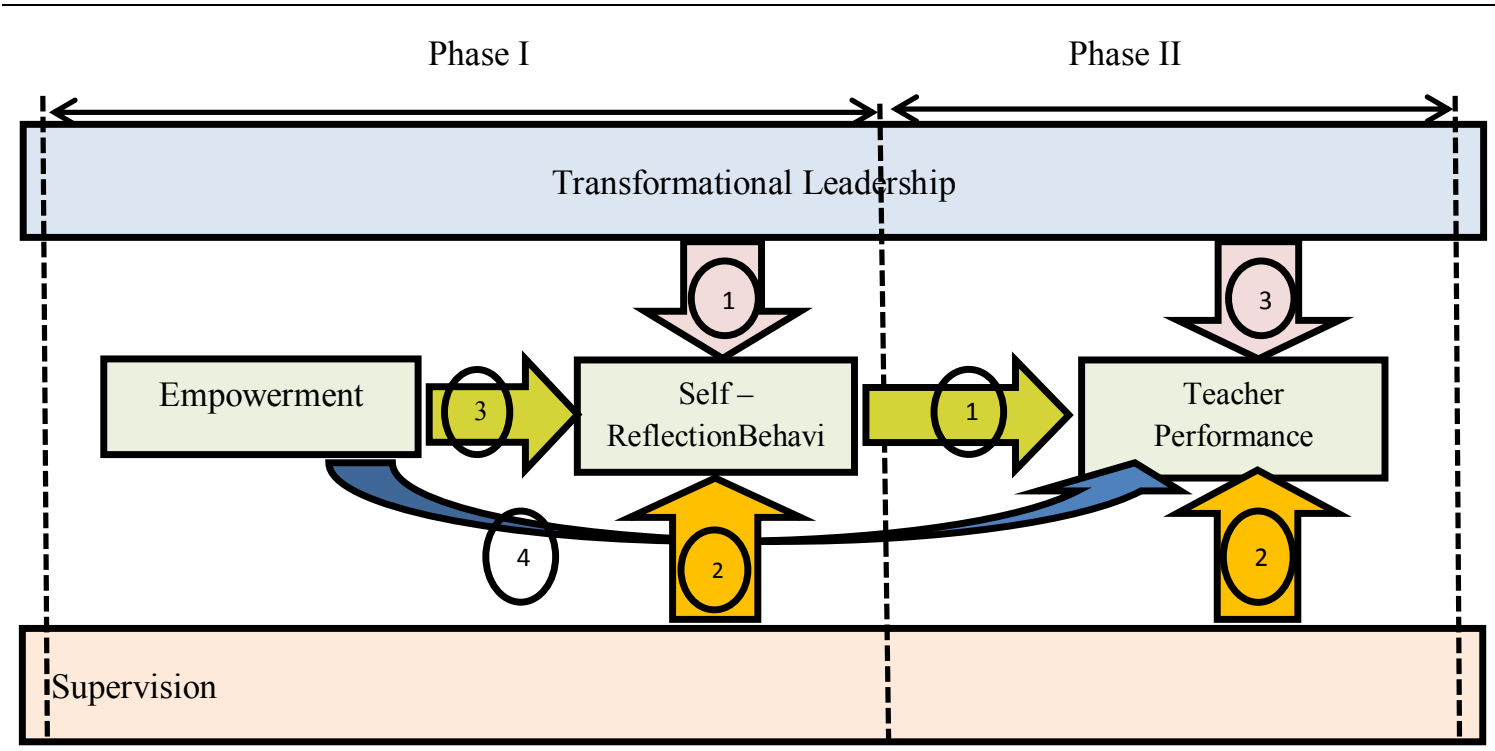

Figure 3:Model of theDevelopment ofTeacher Performance of High School

Figure3shows Model of theDevelopment ofTeacher Performance of High School is composedoftwostagesin theapplicationprocess. PhaseI explainshowthe influenceof the threevariablesthatcome from outside theteachers themselves, the school principal, in improvingthe self-reflection behavior of teacher, becauseresearch findingsindicatethatself-reflection behaviorof teachers isthe most influential variableon improvingteacher performance. Thus it canbe saidthatif you want toimprove the performance ofthe teacher, then theteacherself-reflection behaviorneeds to be improvedfirst.Increasingteacherself-reflection behaviorcharacterized by increasedright attitudetowards work, displaya steadypersonality, positiveperceptions, and their willingnessto learn, andalwaysthinkinganddialoguewith oneself about his/her job. The threevariablesthat influencethe increaseof self-reflection behaviorof teachers, fromthelargest tothe smallest, respectivelyare: (1) the principaltransformational leadership, (2) supervisionof teachersby principals, academic and administrative, and(3) empowermentteachersbyprincipals.

Subsequently, PhaseIIexplainshowthe influenceofthe fourvariables inPhaseI on thevariablesof teacher performance. The second phaseshowsthat theimprovementof teacher performancecan becarried out simultaneouslyamongthe factorsthatoriginate outsidethe teacher's own (principal), andfactors thatoriginatefromteachers themselves. In other words, an increase inteacher performancecanbe doneby increasingthe capacity ofschool principalsinthe field oftransformational leadership, teacher empowerment, andteachersupervision, as well asthe effortsof theteachers themselvesto improveher self-reflection. Fourvariables thataffect theimprovement ofteacher performance, fromthelargest tothe smallest, respectivelyare: self-reflection behaviorof teachers, (2) supervisionof teachersby principals, academic and administrative, (3) the principaltransformational leadership, and(4) empowermentof teachersby principals.

\section{CONCLUSION}

Improvedteacher performancecan bedone in twostages, the first stagethrough increasingthecapacity of school principalsinthe field oftransformational leadership, supervisionof teachers, andteacher development. Increasingthe capacityofprincipalshas an influenceon theimprovement ofteacherself-reflection behavior. The second stageisthrough increasedteacherself-reflection itself.Increasingteacherself-reflection behaviorhave an impact onincreasingthe activity ofthe thinkinganddialoguewith oneselfbyteachersaboutteachingactivityhas been, is, andwillbe implementedin order to improvethe quality oflearning.

\section{Acknowledgements}

I thank Professor Dr. SyaifulSagala, Professor Dr. Abdul MuinSibuea, Professor ParlindunganPangaribuan, MA, Ph. D, Professor HarunSitompul, and Professor Dr. Sukirno, Graduate Program, State University of Medan, for hisinsights and consultation with the final manuscript.

\section{REFERENCES}

[1] Gibson at. al, Organization bahavior, structure, process (Boston: Mc Graw Hill, 2009)

[2] IdawatiD, SuccessfulLeaders(Jakarta: PPM Graduate School of Management, 2004)

[3] Ministry of Education and Culture of Human Resources Development Education and Culture and Education Quality Assurance, Manual application of result of Teacher Competency Test (TCT) Online Report Phase I, 2012

[4] Arifin, Effect ofimplementation ofthe policyof academicqualificationand certificationof thecompetence ofthe teachereducatorsforelementaryschoolteachersinthe districtBelitungofBangka Belitungislands province(Bandung: Graduate ProgramPadjajaran University, 2009) 
[5] Yuliani Indrawati, Factors thataffectthe performance ofmath teachersin the implementation ofcompetency-basedcurriculum(CBC)in High School Palembang city, Journal Manajemen andBusiness Sriwijaya, 4 (7), 2006, 57

[6] Stephen Robbinsand Mary Coulter, Management.International Edition(New Jersey: Pearson Prentice Hall,2007)

[7] Dadi Permadi and Daeng Arifin, The smiling teacher (Bandung: CV. Nuansa Aulia, 2010)

[8] Rusman, Learning Models(Bandung: Mulia Mandiri Press, 2010)

[9] WinaSanjaya, The implementationof competence-based curriculum(Jakarta: PrenadaMedia, 2005)

[10] E. Mulyasa,Competencystandardsandteacher certification(Bandung: RemajaRosdakarya, 2007)

[11] John Hall, Master of Agribusiness student; Shannon Johnson, Master of Agribusiness student; Allen Wysocki, Assistant Professor; and Karl Kepner, Distinguished Professor; Department of Food and Resource Economics, Florida Cooperative Extension Service, Institute of Food and AgriculturalSciences, University of Florida, Gainesville, FL 32611, fromhttp://edis.ifas.ufl.edu/ pdffiles/hr/hr02000.pdf, (March 2013)

[12] Hesselbein, Frances, and Paul M. Cohen, Leader to leader (San Francisco, CA: Jossey-Bass Publishers, 1999)

[13] Northouse, Peter G., Leadership theory and practice, second edition (Thousand Oaks, CA: Sage Publications, Inc., 2001)

[14] Gibson, Ivancevich, Donnelly, Konopske, Organizations bahavior, stukture, process (Boston: Mc Graw Hill, 2009)

[15] Fred C. Lunenburg, and Allan C. Ornsten, Educational administration (Belmont USA: Wadsworth, 2000)

[16] Bernard Bass and B.J. Avolio, Improving organizational effectiveness through transformational leadership, (Sage, Thousand Oaks, 2005)

[17] Freud Luthans, Organization behavior tenth edition (Boston : Mc Graw -Hill International Edition, 2005)

[18] Jhon R Schermerhorn, Hunt James and Osborn Richard N,Organizational behavior (United State of America: Jhon Wiley \& Sons Inc, 2005)

[19] Nelson Debra L. And Quick Campell James, Organizational behavior(Australia : Thomson, 2006)

[20] Freud Luthans, Organization behavior tenth edition (Boston : Mc Graw -Hill International Edition, 2005)

[21] Clutterbuck David, Kernaghan Susan, The power of empowerment release the hidden talents of your employees, translate byBern Hidayat(Jakarta: Gramedia, 2003)

[22] Mc Shane, Steven,L., Glinow Von Mary, Ann, Organizational behavior (Boston: Mc Grwa-Hillim, 2005)

[23] Nelson Debra L. And Quick Campell James, Organizational behavior (Australia: Thomson, 2006)

[24] Stephan Robbins and Mary Coulter, Management international edition(New Jersey: Pearson Prentice Hall, 2005)

[25] Winardi, History ofThoughtin the Field of Management (Bandung: Mandar Maju, 2002)

[26] Hani T. Handoko, Manajemen edition $2^{\text {th }}$ (Yogyakarta: BPFE, 2000)

[27] Stephan Robbins and Mary Coulter, Management international edition,(New Jersey: Pearson Prentice Hall, 2005)

[28] Kemmis, S.,Action Research and the Politics of Reflection, Chapter 10 in Boud, D., Keogh., and Walker, D. (eds) Reflection: Turning experience into learning(London: Kogan, 1985)

[29] Asep Sapa'at, Stop to be teacher! (Jakarta: PT. Tangga Pustaka, 2012)93-98

[30] Wiggens,Sam P., The student teacher in action (New York: John Wiley, 1957)

[31] Boud D, Keogh R and Walker D., Reflection: Turning experience in to learning (London: Kogan Page, 1985)

[32] Fred Korthagen and Angelo Vasalos, Theory and practice, Journal: Teachers and Teaching, 11 (1), 2005, 47-71 